\title{
Diagnosis and treatment of urinary tract complications in Crohn's disease: An experience over 15 years
}

\author{
Haim Ben-Ami MD, Yeoshua Ginesin MD, Doron M Behar MD, \\ Doron Fischer MD, Yeouda Edoute MD PhD, Alexandra Lavy MD
}

H Ben-Ami, Y Ginesin, DM Behar, D Fischer, Y Yeouda, A Lavy. Diagnosis and treatment of urinary tract complications in Crohn's disease: An experience over 15 years. Can J Gastroenterol 2002;16(4):225-229.

BACKGROUND: Urinary tract complications in Crohn's disease are common but treatable, and often present diagnostic and therapeutic dilemmas.

PURPOSE: To determine the incidence of urinary tract complications in patients with Crohn's disease in Israel and to report an experience over 15 years of patients with Crohn's disease, with the aim of illustrating the diverse patterns of presentation, and thereby broadening the approach to diagnosis and treatment.

METHODOLOGY: Clinical and radiological findings of 312 patients with Crohn's disease were reviewed.

RESULTS: Simple cystitis was the most common problem, occurring in 51 patients. The problem seldom required hospitalization and was instead managed in the ambulatory setting. A review revealed that 22 patients with urinary tract complications required hospitalization. Six patients had ileovesical fistulas. In one patient, the colon was also affected. In another patient, radiological and endoscopic studies failed to identify the fistula, which was confirmed during surgery. All six patients were treated surgically. Four patients had ureteral obstructions and hydronephrosis, three of whom responded well to conservative treatment. In one patient, the affected ileal segment was resected. Four patients suffered from retroperitoneal abscess accompanied by urinary symptoms. Twelve patients developed right kidney stones. All of the patients suffered from long-standing Crohn's disease with bowel resection. Surprisingly, most of the severe complications occurred in men, although $70 \%$ of the patients were women.

CONCLUSIONS: Based on these findings, urological complications are not rare in patients with Crohn's disease, and necessitate a high degree of diligence and periodic urological evaluation.

Key Words: Crohn's disease; Urinary complications

Résumé à la page suivante

Department of Internal Medicine C, Urology, Diagnostic Radiology and Gastroenterology, Rambam Medical Center and The Bruce Rappaport Faculty of Medicine, Technion, Israel Institute of Technology, Haifa, Israel

Correspondence: Dr Haim Ben-Ami, Deputy Director, 21 Haagana Street, 28077 Kiryat Ata, Israel. Telephone +972-4-854-3309,

fax+972-4-854-2260, e-mail mdhaim@tx.technion.ac.il

Received for publication July 16, 2001. Accepted January 23, 2002 


\section{Le diagnostic et le traitement des complications du tractus urinaire dans la maladie de Crohn : Une expérience de plus de 15}

HISTORIQUE : Les complications du tractus urinaire dans la maladie de Crohn sont des troubles courants mais traitables qui s'associent souvent à des dilemmes diagnostiques et thérapeutiques.

OBJECTIF : Établir l'incidence de complications du tractus urinaire dans la maladie de Crohn en Israël et rendre compte d'une expérience de plus de 15 ans avec la maladie de Crohn, afin d'illustrer les divers schèmes de présentation et d'ainsi élargir la méthode de diagnostic et de traitement. MÉTHODOLOGIE : Examen des observations cliniques et radiologiques de 312 patients atteints de la maladie de Crohn

RÉSULTATS : La cystite simple est le trouble le plus courant. Elle s'observe chez 51 patients. Le problème exige rarement une hospitalisation et est plutôt traité en clinique externe. Un examen révèle que 22 patients souffrant de complications du tractus urinaire ont dû être hospitalisés. Six patients présentaient une fistule iléovésicale. Chez l'un d'eux, le côlon était également touché. Chez un autre patient, des examens radiologiques et endoscopiques n'ont pas permis de repérer la fistule, dont la présence a été confirmée au moment d'une opération. Les six patients ont été opérés. Quatre patients souffraient d'une obstruction urétérale et d'une hydronéphrose, et trois ont bien réagi à un traitement conservateur. Chez le quatrième patient, le segment iléal atteint a été réséqué. Quatre patients ont souffert d'un abcès rétropéritonéal accompagné de symptômes urinaires. Douze patients ont développé un calcul du rein droit. Tous étaient atteints d'une maladie de Crohn de longue date et avaient subi une résection intestinale. Curieusement, la plupart des complications graves s'observaient chez les hommes, bien que $70 \%$ des patients étaient des femmes.

CONCLUSIONS : D'après ces observations, les complications urologiques ne sont pas rares chez les patients atteints de maladie de Crohn, et elles justifient un taux de diligence élevé ainsi qu'une évaluation urologique périodique.

\section{$\mathrm{C}$} rohn's disease of the small or large intestine may involve the urinary tract at several different sites and in various ways. Urological complication is a leading cause of surgical intervention in patients with Crohn's disease.

The many complications of Crohn's disease include fistulas, which are so frequent that they constitute a cardinal feature of this disease. Most fistulas occur between adjacent loops of bowel, between the bowel and abdominal wall, and between the bowel and perianal tissues. More rarely, fistulas may occur between the intestine and the urinary bladder (1), resulting in recurrent urinary tract infections. An additional urological complication may be caused by an abscess or inflammatory mass of the bowel, causing ureteral obstruction (2-5).

No study on urinary tract complications in patients with Crohn's disease has yet been done in Israel. Due to the increasing prevalence of Crohn's disease in Israel, the importance of diagnosis and management of these complications has increased. We report our experience with 312 patients with Crohn's disease cared for over 15 years, with particular emphasis on urological complications.

\section{PATIENTS AND METHODS}

The diagnosis of Crohn's disease was confirmed based on clinical, radiological and histopathological criteria. During the period 1984 to 1999,312 patients with Crohn's disease were treated at the Rambam Medical Center, Haifa, Israel a tertiary referral hospital serving a population of one million. Of the 312 patients, 221 were women and 91 were men, with ages ranging from 16 to 67 years (mean 41 years). All charts and imaging studies of these patients were reviewed. Prior history was sought with respect to duration and distribution of disease, past surgical and medical therapy, and presenting symptomatology. The duration of the disease varied from one to 31 years, with an average of nine years between the onset of Crohn's disease and urinary tract complications. Intravenous pyelograms were available in

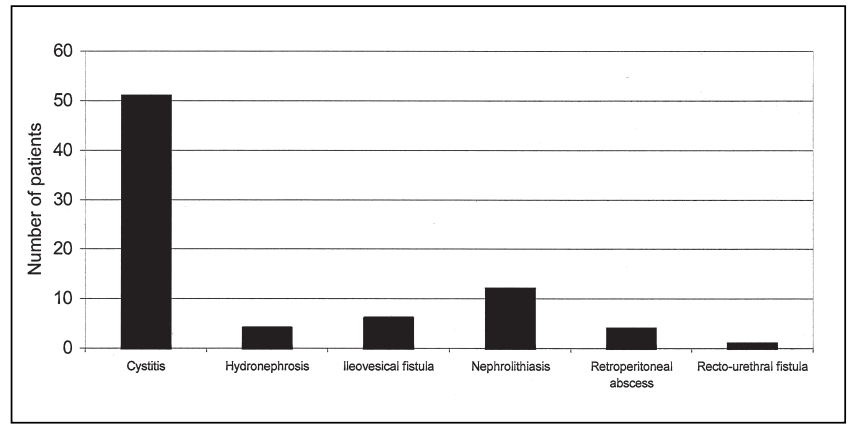

Figure 1) Urological complications among 312 patients with Crohn's disease

62 patients. Long term patient status was ascertained from the medical records of 281 patients and telephone interviews of 31 patients. All patients underwent periodic urological evaluation (annual renal ultrasonography and a urinogram) as part of the long term management of Crohn's disease. When necessary, additional information was obtained from the referring physicians, from medical records of other hospitals and from families of the patients.

\section{RESULTS}

Seventy-seven patients had urinary symptoms with or without structural involvement of urinary tract by the inflammatory process. Thus, the incidence of urological symptoms present throughout the course of Crohn's disease was 24.7\%. The types of complications are listed in Figure 1.

\section{Cystitis (51 patients)}

Inflammation of the bladder was the most common urological complication of Crohn's disease at $16.3 \%$ - a rate higher than that reported in patients with ulcerative colitis. It occurred mostly in patients with structural involvement of the urinary tract. The diagnosis was made on the basis of the clinical history and the urine culture. Eighty per cent of 
TABLE 1

Characteristics of patients with Crohn's disease associated with hydronephrosis

\begin{tabular}{|c|c|c|c|c|c|c|}
\hline Sex & $\begin{array}{c}\text { Age } \\
\text { (years) }\end{array}$ & $\begin{array}{l}\text { Location of } \\
\text { obstruction }\end{array}$ & $\begin{array}{c}\text { Period between the } \\
\text { onset of Crohn's disease } \\
\text { and hydronephrosis (years) }\end{array}$ & Mode of treatment & $\begin{array}{c}\text { Recurrence of } \\
\text { hydronephrosis }\end{array}$ & $\begin{array}{c}\text { Follow-up } \\
\text { (years) }\end{array}$ \\
\hline Male & 26 & Right ureter & 4 & $\begin{array}{c}\text { 'Pulse' therapy, } \\
\text { percutaneous nephrostomy, } \\
\text { ureteral stent }\end{array}$ & No recurrence & 11 \\
\hline Male & 22 & Right ureter & 1 & $\begin{array}{c}\text { 'Pulse' therapy, percutaneous } \\
\text { nephrostomy, ureteral stent }\end{array}$ & No recurrence & 4 \\
\hline Male & 37 & Left ureter & 15 & $\begin{array}{c}\text { 'Pulse' therapy, percutaneous } \\
\text { nephrostomy, ureteral stent }\end{array}$ & No recurrence & 3 \\
\hline Female & 19 & Right ureter & 2 & Ileal resection & No recurrence & 4 \\
\hline
\end{tabular}

TABLE 2

Characteristics of patients with Crohn's disease associated with urolithiasis

\begin{tabular}{lccccccc}
\hline Sex & $\begin{array}{c}\text { Age } \\
\text { (years) }\end{array}$ & Location & $\begin{array}{c}\text { Uric oxalate } \\
\text { (mg/day) }\end{array}$ & $\begin{array}{c}\text { Period between surgery } \\
\text { and initial urinary } \\
\text { symptoms (years) }\end{array}$ & $\begin{array}{c}\text { Mode of } \\
\text { treatment }\end{array}$ & $\begin{array}{c}\text { Recurrence of } \\
\text { urolithiasis }\end{array}$ & $\begin{array}{c}\text { Follow-up } \\
\text { (years) }\end{array}$ \\
\hline Female & 23 & Ureter & - & 4 & Medication & No recurrence \\
Male & 25 & Ureter & - & 6 & PCNL & No recurrence & 5 \\
Male & 28 & Ureter & 66.4 & 5 & Medication, SUP & No recurrence & 7 \\
Male & 32 & Kidney & - & 5 & PCNL & No recurrence & 7 \\
Male & 39 & Ureter & - & 6 & Medication & No recurrence \\
Female & 33 & Ureter & 69.4 & 7 & Medication, SUP & No recurrence \\
Male & 33 & Ureter & 64.7 & 8 & Medication, SUP & No recurrence \\
Male & 41 & Ureter & - & 9 & Medication & No recurrence \\
Male & 42 & Ureter & - & 11 & PCNL & No recurrence \\
Male & 43 & Ureter & - & 9 & EML & Ureterolithiasis recurrence & 9 \\
Male & 45 & Ureter & - & 17 & EML & No recurrence
\end{tabular}

${ }^{\star}$ Normal range 5 to $40 \mathrm{mg} /$ day. EML Endoscopic mechanical lithotripsy; PCNL Percutaneous nephrolithotripsy; SUP Spontaneous urinary passage

patients were female. In $89 \%$ of patients, the urinary tract infection was recurrent, with usually two to three attacks per year. The most common microorganism to be cultured from the urine was Escherichia coli; in some cases Streptococcus faecalis or Klebsielleae species were identified.

Hydronephrosis (four patients)

Intravenous pyelograms were available in 62 patients, and renal ultrasonography in 115 patients. Four patients (three male, one female) had marked hydronephrosis (Table 1); the right kidney was affected in three patients, and the left kidney was affected in one patient. An obstruction was identified by ultrasonography and/or pyelography. The mean duration between the onset of Crohn's disease and the diagnosis of hydronephrosis was 5.6 years. Three patients responded well to 'pulse therapy' with corticosteroids (hydrocortisone sodium succinate $300 \mathrm{mg} / \mathrm{day}$ for seven days), percutaneous nephrostomy and ureteral stent insertion. All patients underwent post-treatment intravenous pyelography showing resolution of the obstructed ureter. The nephrostomy was closed and removed.
Corticosteroid doses were tapered. In one patient, the symptoms improved by preoperative total parenteral nutrition, but resection of the affected ileal segment was necessary. No recurrence of hydronephrosis has occurred.

Urolithiasis (12 patients)

The main symptoms of urolithiasis were back and flank pains. All of these patients with urolithiasis suffered from long-standing Crohn's disease and had undergone surgery. The mean duration between the surgery and the symptoms of urolithiasis was 7.2 years (range four to 17 years). Of 12 patients (10 male and two female) with urolithiasis, $11 \mathrm{had}$ ureter stones and one had a renal stone (Table 2). Biochemical analysis of urine revealed calcium oxalate crystals in three patients. The daily output of the urinary oxalate concentration measured in two patients was increased. Five of 12 patients underwent either percutaneous nephrolithotripsy or endoscopic mechanical lithotripsy. In one patient, another calculus was found and removed nine years later. Interestingly, all of these patients developed urolithiasis on the right side. 
TABLE 3 Patients with Crohn's disease associated with
enterovesical fistulas

\begin{tabular}{|c|c|c|c|c|}
\hline Sex & $\begin{array}{c}\text { Age } \\
\text { (years) }\end{array}$ & Site of fistula & $\begin{array}{l}\text { Period between } \\
\text { the onset of } \\
\text { Crohn's disease and } \\
\text { initial urinary } \\
\text { symptoms (years) }\end{array}$ & Treatment \\
\hline Male & 33 & $\begin{array}{l}\text { Ileovesical } \\
\text { resection }\end{array}$ & 11 & Ileocecal \\
\hline Male & 21 & $\begin{array}{l}\text { Ileovesical } \\
\text { resection }\end{array}$ & 4 & Ileocecal \\
\hline Male & 41 & $\begin{array}{l}\text { Sigmoidovesical } \\
\text { colectomy }\end{array}$ & 0 & Subtotal \\
\hline Male & 39 & $\begin{array}{l}\text { Ileovesical } \\
\text { resection }\end{array}$ & 21 & Ileocecal \\
\hline Male & 27 & $\begin{array}{l}\text { Ileovesical } \\
\text { resection }\end{array}$ & 1 & Ileocecal \\
\hline Male & 47 & $\begin{array}{l}\text { Ileovesical } \\
\text { resection }\end{array}$ & 19 & Ileocecal \\
\hline
\end{tabular}

\section{Enterovesical fistulas (six patients)}

Patients with enterovesical fistulas were all male. Crohn's disease had been diagnosed before the appearance of urinary symptoms in five patients, whereas one patient had vague and still undiagnosed abdominal pain and diarrhea when the urinary complication was discovered (Table 3 ). The mean duration between the onset of Crohn's disease and the initial symptoms of urinary fistulas was 11.2 years (range one to 21 years). Three patients had pneumaturia, and one had fecaluria; one patient claimed to have passage of urine per rectum. Gastrointestinal barium studies failed to identify the fistulas in all patients. Computed tomography scan diagnosed a fistula in one patient with air and contrast material in the bladder. In four patients, the diagnoses were achieved by cystoscopy. One patient presented with puzzling bladder symptoms, and neither radiological nor endoscopic studies identified a fistula. On further investigation, the pneumaturia was presumed, and an ileovesical fistula was confirmed at surgery. The sites of fistulas were ileovesical in five patients and sigmoidovesical in one patient. One-stage resection of the affected bowel segment was performed in these patients with the intent of removing the fistula. No patients required resection of the bladder. No recurrence of fistulas was observed during the follow-up period.

\section{Retroperitoneal abscess}

Four patients suffered from retroperitoneal abscess accompanied by urinary symptoms. However, no direct involvement of the urinary tract was found.

\section{DISCUSSION}

The pathological effects of Crohn's disease on the urinary tract may manifest with two principal presentations - as an inflammatory process, which may lead to fistula formation, cystitis, perivesical abscess and ureteral obstruction, or as metabolic abnormalities, which predispose patients to nephrolithiasis (6). Any of these complications may present at any stage, and even may appear as the initial presenting symptom of Crohn's disease. Usually, they occur in patients with severe, long-standing disease. Early recognition and appropriate therapy are crucial to avoid serious sequelae, which may include loss of renal function.

Most of the patients with urinary symptoms in the present series had proven Crohn's disease for many years. Although cystitis is frequent in female patients, even in the absence of inflammatory bowel disease, the association with structural involvement of the urinary tract explains the high rate of recurrent urinary tract infections in this series.

The incidence of hydronephrosis is considered to be as high as $6 \%$, with the right ureter being involved in most cases. Its occurrence does not always imply long-standing, severe disease. It may occur at any age or at any stage of the process. There are several options regarding the surgical treatment of ureteral obstruction. Block et al (7) reported ureterolysis to be necessary, whereas others $(8,9)$ stated that ureterolysis is rarely indicated and recommended the resection of an involved intestine. Because the ureteral involvement in Crohn's disease is usually an extrinsic obstruction, a ureteral catheter can be inserted in either the retrograde or antegrade direction, following percutaneous nephrostomy. The latter procedure can be carried out under local anesthesia and is often more comfortable for the patient. Once an internal ureteral stent is placed, the nephrostomy tube can be removed. This internal stent provides adequate drainage of the kidney and preserves kidney function. The stent may remain in place for three to six months, and during that time the inflammatory process may resolve with medical therapy. Usually, the internal stent does not cause discomfort, although irritation of the urinary bladder may cause dysuria. Periodic follow-up using appropriate imaging modalities (ultrasound, intravenous pyelogram, computed tomography or renal scan) is highly recommended. In the present study, hydronephrosis had resolved in three of four patients with this treatment. Therefore, we would like to emphasize the effectiveness of this approach.

The reported incidence of nephrolithiasis in patients with inflammatory bowel disease is up to $19 \%$, in contrast to only $0.1 \%$ in the general population $(10)$. The majority of patients with Crohn's disease and calculi have undergone surgery, as in the present series. Interestingly, all patients in the present study developed nephrolithiasis on the right side, reflecting the greater propensity to involve the right ureter. The medical treatment of urolithiasis in Crohn's disease is conservative, initially, and includes pain control, hydration and alkalinization of the urine, especially in patients with urate stone. This conservative treatment is effective in most cases, but sometimes urological treatment, such as endoscopic mechanical lithotripsy and percutaneous nephroureterolithotomy, should be considered. The pathophysiology behind the genesis of oxalate stones is of particular interest and has been attributed to the increased 
urinary oxalate excretion, owing to increased intestinal absorption. Most of the dietary oxalate is bound to calcium and is poorly absorbed, but malabsorbed fats in patients with ileal resection bind intraluminal calcium, decreasing the amount bound to oxalate and resulting in increased oxalate absorption (10). After successful management of the index stone, prevention of recurrence is imperative because stones tend to recur. Increased fluid intake to ensure high urine output, low oxalate diet, alkalinization of urine and citrate supplementation are an integral part of treatment. In addition, pyridoxine, which decreases oxalate synthesis, may be helpful.

Fistula from the ileum into the bladder is more common in males than in females, because in females, the uterus and vagina afford some protection to the posterior wall and base of the bladder. In the male, a heavy thickened loop of dis-

\section{REFERENCES}

1. Yamamoto T, Keighly MR. Enterovesical fistulas complicating Crohn's disease: clinicopathological features and management. Int J Colorectal Dis 2000;15:211-5.

2. Klevmark B, Nygaard K. Reversible ureteral stenosis as a delayed complication of operation of the colon and rectum. Acta Chir Scand 1975;141:153-9.

3. Mooney RAH, Sant GR. Obstructive uropathy in granulomatous bowel disease. Br J Surg 1973;60:525-31.

4. Present DH, Rabinowitz JG, Banks PA, et al. Obstructive hydronephrosis. A frequent but seldom recognized complication of granulomatous disease of the bowel. N Engl J Med 1969;280:523-8.

5. Rabinowitz JG, Present DH, Banks PA, et al. The roentgenographic features of ureteral obstruction secondary to granulomatous disease of the bowel. Clin Radiol 1971;22:205-8.

6. Manganiotis AN, Banner MP, Malkowicz SB. Orologic complications of Crohn's disease. Surg Clin N Am 2001;81:197-215.

7. Block GE, Enker WE, Kirsner JB. Significance and treatment of occult obstructive uropathy complicating Crohn's disease. Ann Surg 1973;178:323-32.

8. Siminovitch JM, Fazio VW. Ureteral obstruction secondary to Crohn's disease: a need for ureterolysis? Am J Surg 1980;178:322-32.

9. McNamara MJ, Fazio VW, Lavery IC, et al. Surgical treatment of enterovesical fistulae in Crohn's disease. Dis Colon Rectum 1990;33:271-6. eased ileum may be positioned at the bottom of the pelvis against the bladder base, causing persistent irritation (11). For enterovesical fistulas, the only definitive treatment is resection of the involved bowel (12-20). There is no need to repair the bladder wall because the vesical portion heals spontaneously. The experience with nonoperative management of these patients is small and confined to a highly selected group.

\section{SUMMARY}

Urological complications are common in patients with Crohn's disease. By the time the urinary complication is considered, significant urinary tract damage may have occurred. Awareness of these complications leads to earlier diagnosis and urological management, and decreases the high morbidity associated with these complications.

10. Pardi DS, Tremaine WJ, Sandborn WJ, et al. Renal and urologic complications of inflammatory bowel disease. Am J Gastroenterol 1998;93:505-14.

11. Kyle J. Urinary complications of Crohn's disease. World J Surg 1980;4:153-60.

12. Sato S, Sasaki I, Naito H, et al. Management of urinary complications in Crohn's disease. Surg Today 1999;29:713-7.

13. Stamler JS, Bauer JJ, Janowitz HD. Rectourethroperineal fistula in Crohn's disease. Am J Gastroenterol 1985;80:111-20.

14. Schraut WH, Block GE. Enterovesical fistula complicating Crohn's ileocolitis. Am J Gastroenterol 1984;79:186-91.

15. Van Dongen LM, Lubbers E-JC. Fistulas of the bladder in Crohn's disease. Surg Gynecol Obstet 1984;158:308-12.

16. Greenstein AJ, Sachar DB, Tzakis A, et al. Course of entero-vesical fistulae in Crohn's disease. Am J Surg 1984;147:788-92.

17. Karamchandani MC, West CF Jr. Vesicoenteric fistulas. Am J Surg 1984;147:681-3.

18. Margolin ML, Korelitz BI. Management of bladder fistulas in Crohn's disease. J Clin Gastroenterol 1989;11:399-402.

19. Gorcey S, Katzka I. Is operation always necessary for enterovesical fistulas in Crohn's disease? J Clin Gastroenterol 1989;11:396-9.

20. Smith PJ, Williams RE, de Dombal AT. Genito-urinary fistulae complicating Crohn's disease. Br J Urol 1972;44:657-60. 




The Scientific World Journal
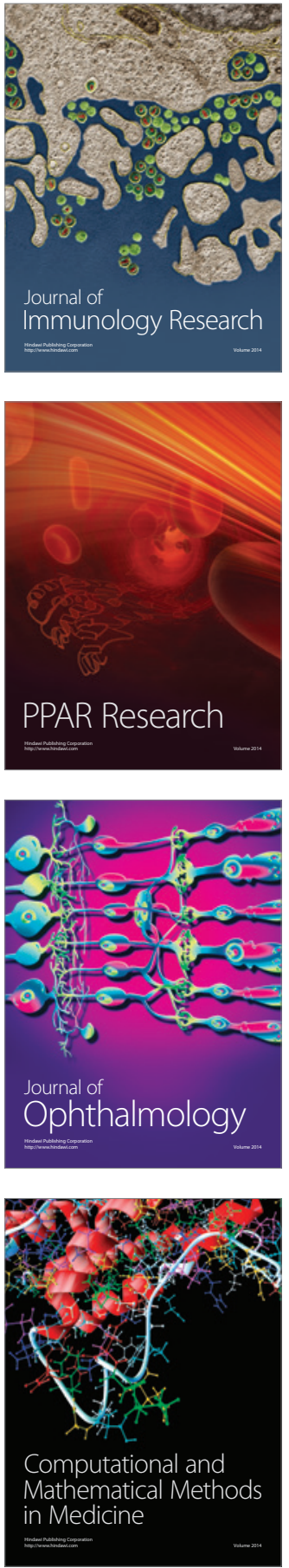

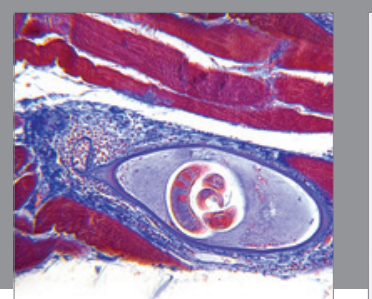

Gastroenterology Research and Practice

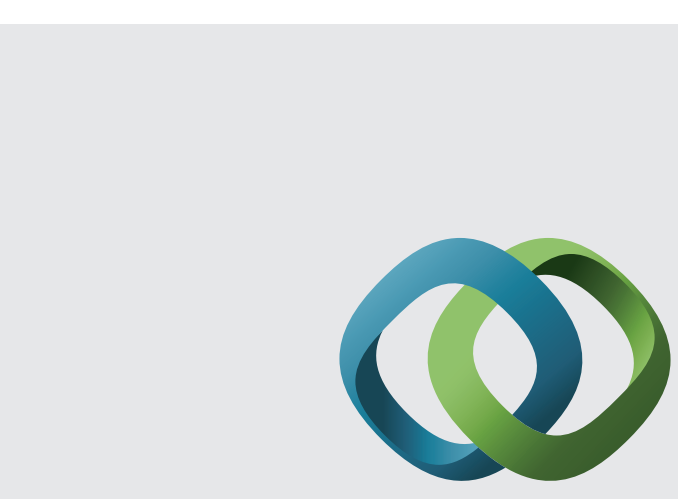

\section{Hindawi}

Submit your manuscripts at

http://www.hindawi.com
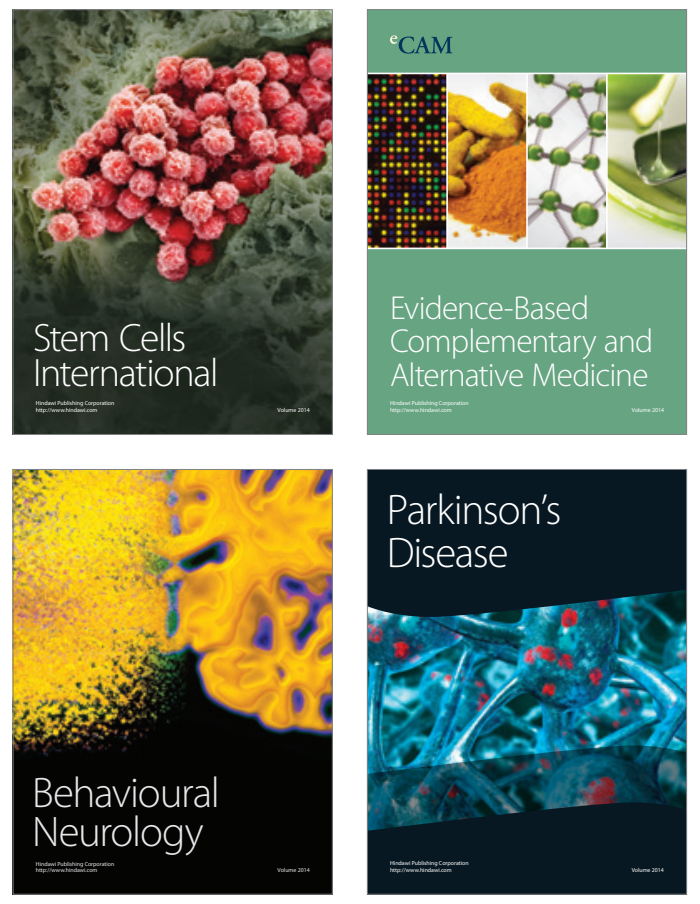


Disease Markers
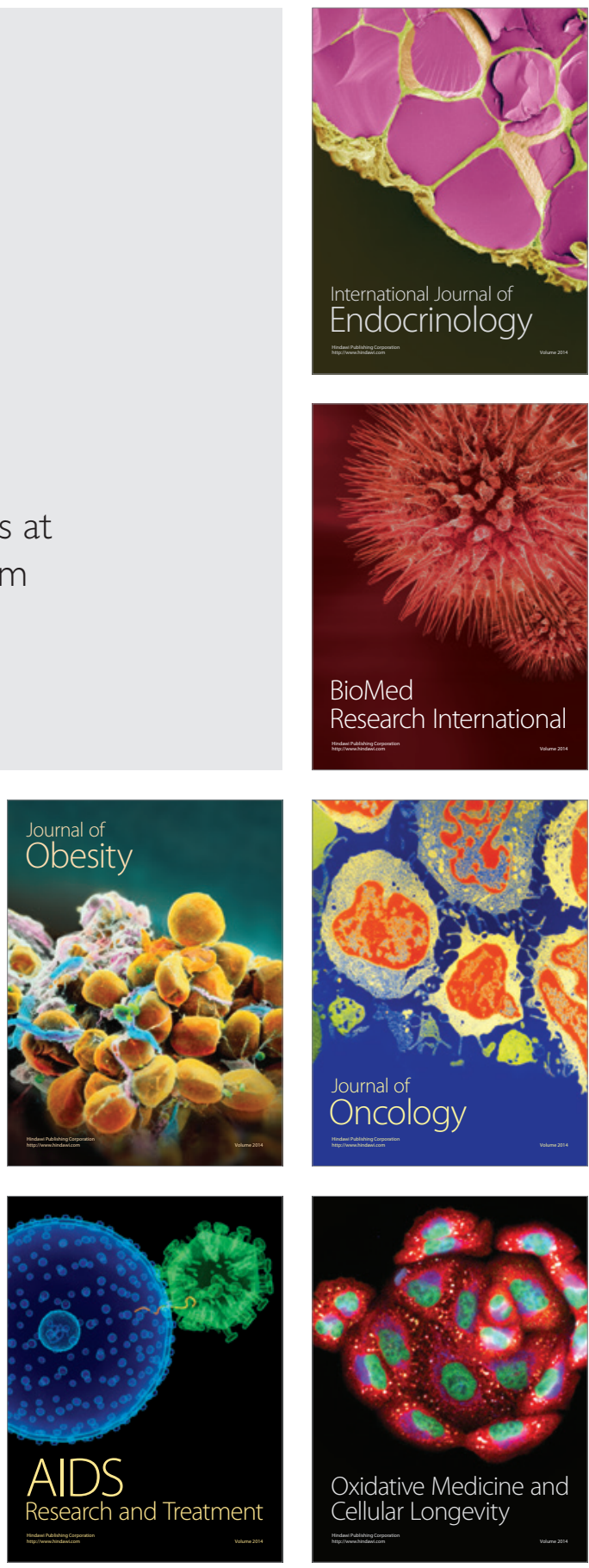